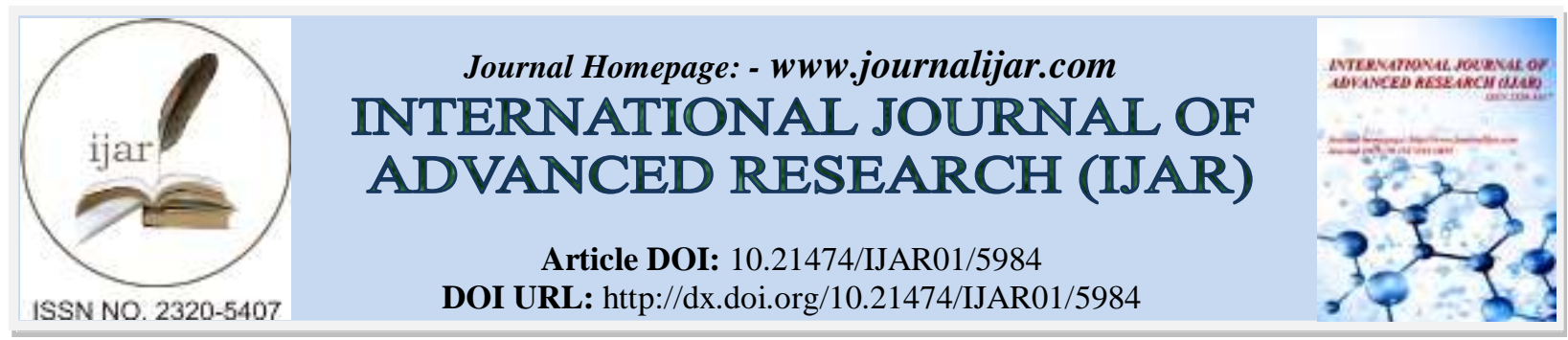

RESEARCH ARTICLE

\title{
ACCREDITATION AS A QUALITY ASSURANCE IN NIGERIA UNIVERSITIES: THE CHALLENGES.
}

\section{S. dada ${ }^{1}$, Yakub Ibrahim Wunti ${ }^{2}$ and Tukei Martin ${ }^{3}$.}

1. PhD Department of Educational Management, Faculty of Education, University of Abuja.

2. PhD College of Education, Open, Distance and e-Learning, Kampala International University, Kampala Uganda.

3. Human Resource Directorate, Kampala International University, Kampala Uganda.

\section{Manuscript Info}

\section{Manuscript History}

Received: 06 October 2017

Final Accepted: 08 November 2017

Published: December 2017

Key words:-

Accreditation, Quality Assurance,

Undergraduate Programmes and

Challenges.

\section{Abstract}

Accreditation of undergraduate programmes emanated owing to The proliferation of universities in Nigeria and the public concerns on the ill preparedness of graduates for work and further studies in Nigeria and elsewhere in the world. Accreditation of undergraduate programmes is conceptualized as the official recognition and approval given to a programme offered in any Nigeria university which has met Benchmark Minimum Academic Standards (BMAS) as established by the external accreditation agency, the National Universities commission (NUC). In this paper, accreditation and quality assurance were seen as related constructs. The NUC's accreditation in Nigeria started in 1999/2000 through processes initiated by the NUC to the Universities. Accreditation in Nigeria has positively impacted on the quality of university education in Nigeria, by setting standards which each university must meet to offer any undergraduate programme. This has significantly unified undergraduates programmes offered in over 129 universities in Nigeria. The major challenges of accreditation in Nigeria includes; paucity of funds, multiplicity of functions performed by NUC, policy/functions overlaps with other agencies, professional bodies and unhealthy relationship between the NUC and the Academic staff Union of Universities (ASUU) in Nigeria. Strengthening NUC's accreditation exercise of undergraduate programmes in Nigeria requires that Federal Government makes special budgetary allocations for accreditation to reduce the cost sharing of accreditation exercises between the NUC and the universities, streamlining NUC's functions on accreditation and deliberate policy review of the functions of NUC and the university senates. Finally, NUC should develop strategies for harmonious relationships with the academic staff of universities, the major players in quality assurance of university education in Nigeria. 


\section{Introduction:-}

University education in Nigeria started following the recommendation of the Elliot Commission of 1943. This gave impetus for the establishment of University College Ibadan (UCI) in 1948. The UCI was an affiliate of the University of London. However, the UCI take-off was bedevilled with a number of problems which included rigid constitutional provisions, poor staffing, low enrolment and high drop-out rate among others (Ajayi and Haastrup, 2008). Furthermore, the university had the features, and philosophy of the University of London and British values and culture.

In 1959, the Ashby Commission was set up among other things, to advise the Federal Government on the educational needs of the country for its first two decades after independence, particularly in respect to her higher education. The commission recommended among others, the establishment of four universities and university coordinating agency in Nigeria, which was to have undisputed control over the affairs of the multi-universities with specific reference to finance, staff and courses offered in the universities (Fafunwa, 1995). This was a land mark achievement in the development of university education in Nigeria; the first indigenous universities established reflecting the philosophy, the need and aspiration of the Nigerians.

Thus in 1960, the University of Nigeria, Nsukka was established. It was followed by Ahmadu Bello University, Zaria, the then University of Ife, (now Obafemi Awolowo University), the University of Lagos all in 1962 and In 1972, University of Benin was established. The University College, Ibadan, was granted full-fledged university status by the University of Ibadan Act of 1962, (Nwadiani and Igineweke, 2005). These six universities are collectively referred to as the first generation universities and existed as distinct institutions, each with its distinct identity. However, they all had a number of common features (Fafunwa, 1995). Their objectives and structures were similar and each had a council and senate. The senate was responsible for, among other things, determining the admission requirements and other matters related to universities administration (Taiwo, 1994).

In addition, in 1962 the National Universities Commission (NUC) was established, it operated from the office of the prime minister. NUC became a statutory body in 1974. Its main objective was the coordination of the activities of the university system to ensure national unity and uniformity in academic standards. At the take-off of NUC, its function was mainly advisory, as well as liaising amongst universities, government departments and ministries. The National Universities Commission also acted as a channel for government funding of universities, (NUC, 1988).

With the creation of more states in Nigeria in 1967, there were agitations for increase in the number of universities. Between 1975 and 1977, seven more universities were established thereby bringing the number of universities to thirteen. The growth of the university system in Nigeria4 is rooted in the oil boom of 1970s, which saw a substantially improvement in the government revenue position and the increased need for economic and technological advancement of the country (Imam, 2003).

The Federal Government made efforts towards providing conducive environment for teaching, learning and research. According to Oyeonuru (2005) the period from inception of the universities to 1970s was characterised by comfortable shared students' hostel accomodations. Adequate facilities were provided to ensure effective learning for qualitative university education. University libraries were well equipped, maintained and stocked with current books and journals. Adequate laboratories were available and in good shape for practicals. Similarly, classrooms and lecture theatres were adequate and recreational facilities available. The quality of education in Nigerian universities in 1970s met the global standards; producing good and high quality graduates (Okebukola, 2006). University education was considered relevant, responsive, functional and of high quality. Nigerians and the graduates enjoyed high reputations and commanded respect for high standard from the international community.

The universities in Nigeria continued to grow in terms of number and programme offerings. It must be noted however, that between 1980s and early 1990s, the number of universities had increased to thirty seven (Imam, 2003). By 2010, the number of universities increased astronomically bringing the total number of approved universities to 104; out of which are 27 federal universities, 36 states universities and 41 private-owned universities (Teachers Registration Council of Nigeria- TRCN, 2010). The phenomenal growth in number of universities has increased the coordinating task of the National Universities Commission.

In 1974, NUC became a parastatal in the Federal Ministry of Education and a statutory commission charged with the responsibility of regulating the academic, administrative, and the financial activities of Nigerian Universities 
(Okojie, 2010). Furthermore, to ensure that quality was not compromised for quantity, the Federal Government promulgated decree, Decree 16 of 1985 as contained in the NUC amended Decree 49 of 1988 and consequently in the National Minimum Standards and Establishment of Institutions Act of 1993, which empowered NUC to lay down Minimum Academic Standards (MAS) and to conduct accreditation for all undergraduate programmes in Nigeria. It also gave the NUC legal backing to have greater control on university education, this brought about centralisation of university administration and the uniformity in terms of the nature and contents of universities academic programmes. The mandate of the NUC has been expanded to include the following:

1. Approval of courses and programmes;

2. Determination and maintenance of Minimum Academic Standards;

3. Monitoring of Universities;

4. Accreditation of Academic Programmes, and

5. Provision of guidelines and processing of applications for the establishment of private universities (Okojie, 2010).

However, the Universities Act 2003, amended 2007 provide for the University Senate to, among other things, formulate, modify or review curriculum for the organization of Faculties and Departments and to assign to such Faculties and Departments their respective subjects. In the exercise of this power, the Universities establish new programmes to meet the demand of the economic and political realities in Nigeria.

On the otherhand, the mandate of NUC is to carry out verification and accreditation of all the programmes established byb the universities senate; this is to assure that universities meet Minimum Academic Standards (MAS). This also entails ascertaining that universities do not over shoot their admission quota and the carrying capacities. In addition, the NUC is to assure that universities observe in the admission exercise basic entry requirements and those academic contents of programmes meet specified standards for award of degrees. Furthermore, it is to ensure that universities achieve the academic staff mix and teacher/student ratios for all academic programmes. Finally, NUC is to ensure that there are adequate human resources, materials and physical facilities for the establishment of new programmes in the universities (NUC, 2004). These policy positions bring about fuctions overlaps between the university senates and the NUC, the external accreditation body.

\section{Accreditation of Undergraduate Programmes in the Nigeria Universities:-}

Historically, the NUC got its' legal backing from the prorogation of Section 10, Act No. 16 of 1985 , sub -section 4(m) of the NUC amended Act No. 49 of 1988 which empowered the NUC to lay down MAS for universities in Nigeria and to accredit their degrees and other academic awards. The commission carried out its first accreditation exercise of universities programmes in 1990. The second comprehensive accreditation exercise was in 1999/2000. The commission embarked on the accreditation of the first generation private universities in 2004. Another hight was attained by the commission in 2007, when 942 programmes in 53 universities were accredited (Okojie, 2008). The NUC Accreditation exercise in Nigerian universities is Snow twice in every year, conducting regular accreditation of programmes in the universities.

The need for accreditation of undergraduate programmes in the Nigeria Universities has become eminent than ever. The number of approved universities in Nigeria now is 129 approved by the Federal Government of Nigeria through the National Universities Commission (Oluremi and Kolade 2016). The operations of these institutions without a regulatory body that accredits programmes offered by the respective universities, there would not be uniformity in programmes offered in the universities and a possible compromised of standards in many respects, the ultimate goal of producing a high-level manpower would remain a mirage and the graduates of the system would not be able to compete favourably with their peers in other parts of the world. Hence, the justifications for a regulatory body like the NUC, to oversee and regulate the activities of these universities.

In addition, there is growing concerns by stakeholders; parents, employers, national and internal communities that university graduates in Nigeria are poorly prepared for the world of works (Ansu in Moteru, 2007). This concern is further accentuated with the proliferation of private universities in Nigeria, increased demand of university education arising from population explosion across the globe and the attendant enrolment increase in virtually all tertiary institutions without a corresponding infrastructural development, these further underscores the justification for a central coordinating agency like the NUC with full powers of accreditation to ensure quality assurance is not only attained by the existing and prospective institutions but are also maintained by the universities. 
Accreditation and quality assurance are related in a wider context (Okojie 2008). It is essentially, about Quality and Standard (Oladusun, 2011). According to Harvey (2008) Accreditation is official approval granted by an accrediting agency to an accredited institution at the end of a successful assessment exercise. It could also mean the process by which the quality and standard of educational institutions are assessed.

It is relevant to note that the legal basis for accreditation of academic programmes in Nigeria is derived from Section 10 of Act No. 16 of 1985. This is incorporated as section 4 (m) of the NUC amended Act No. 49 of 1988, which empowers the Commission to lay down minimum standards for all universities in the Federation and to accredit their degrees and other academic awards. On the strength of the Act, the NUC developed a set of Minimum Academic Standards (MAS) to guide Nigerian Universities in the development, implementation and evaluation of their curricula which was reviewed in 2004 as Benchmarks Minimum Academic Standards (BMAS) (Okojie, 2008). The institutional compliance with the stipulated standards is measured through specially designed accreditation instrument, developed by the NUC.

Conceptually, accreditation is a recognition given by a regulatory agency to an educational institutions that satisfy specific standards or quality (Chernay, 2003). Okebukola (2006), defined accreditation as the establishment of the status, legitimacy or appropriateness of an institution programme, it is a self-regulatory process by which governmental and non-governmental, voluntary association or rather statutory bodies grant recognition to educational programs or institution that meet stated criteria of educational quality. The main focus of accreditation is ensuring and maintenance of standards in the academic programme offered in the universities.

Fraser (Abubakar, 2015) defined accreditation as a process by which a non-governmental or private body evaluates the quality of a higher educational institution as a whole or of specific educational programme in order to formally recognized it as having met certain predetermined minimal criteria or standards. The result of this process is usually the awarding of status of recognition and sometimes of a license to operate within time limit validity.

Accreditation could also mean a process by which the quality and standard of educational institutions are assessed. In Nigeria, this quality assurance function is conducted by the National Universities Commission (NUC) for Federal, State and Private Universities (Oladusun, 2011). Accreditation of degree and other academic programmes by the NUC is a system of evaluating academic programmes in Nigerian universities to determine whenever they have met the conditions in the Minimum Academic Standard documents. A process guided by criterial general based on judging and institution in the light of stated purpose (Udom, 1996)

Notably, Professional programme in the Nigeria universities are also subjected to external accreditation by their professional bodies and agencies, according to Oladusun (2011), this is directed on considering professional content of their programmes offered in the Nigeria universities. The Nigerian Medical and Dental Council (NMDC) accredits the professional contents of Medical Programmes, the Council of Legal Education (CLE) assesses the professional contents of Law Programmes; the Council for Registration of Engineering in Nigeria (COREN) accredits the professional contents of the Engineering Programmes while the Institute of Chartered Accountants of Nigeria assesses the professional contents of Accounting Programmes. These functions overlap is capable of breeding conflicts among stakeholder that could undermine the all efforts in quality assurance university education in Nigeria.

\section{Accreditation and Quality Assurance of Undergraduate Programmes in Nigeria:-}

Quality in university education is a multidimensional concept which embraces all functions and activities of a university including teaching, academic programmes, research and scholarship, staffing, students, buildings, facilities, equipment, services to the community and the academic environment. Quality assurance on the other hand, is a system which includes all policies, procedures, processes and actions intended to lead to the achievement, maintenance, monitoring and enhancement of quality through inspection or testing of samples (Rami and John, 2008). It is planned activities and actions necessary to provide adequate confidence that a programme, service or product satisfies given requirements for quality (Olorunfemi and Ashaolu, 2010).

Similarly, Adegbesan (2010) argued that, quality assurance is related to accountability; the two are concerned with maximizing the effectiveness and efficiency of educational systems and services in relation to their contexts, their 
missions and their stated objectives. Quality assurance in education focuses on the learners' entry behaviours, characteristics and attributes including some demographic factors that can inhibit or facilitate their learning; the teachers' entry qualifications, values, pedagogical skills, professional preparedness, subject backgrounds, philosophical orientation; the teaching/learning processes including the structure of the curriculum and learning environment and the outcomes, which are defined for different levels in terms of knowledge, skills and attitudes including appropriate and relevant instruments to assess these objectives (Ehindero, 2004).

Quality assurance helps to establish an institution's good reputation and image by defining standards of achievements, documented procedures for all identified process, establishing ways of responding to issues and clear accountability for outcomes ( Akerele, 2008). Quality assurance of university education has to do with meeting acceptable standards as defined by quality assurance bodies or appropriate academic and professional associations so as to garner greater pubic confidence, more satisfied students, efficient processes and staff who are confident in their jobs (Oyebade, 2008). According to Akerele (2008), through quality assurance, students are more likely to experience better quality instructions, learning materials and interactions with the institution and its staff, leading to enhanced learning outcomes.

According to Uvah (2005) quality assurance in education is a higher evaluation accorded to an educative process that has demonstrated that students' educational development has been enhanced. It also implies achievement of set objectives, fulfilment of the general educational aims of autonomy, ability to participate in reasoned discourse of critical self-evaluation and of coming to a proper awareness of the ultimate contingences of all thought and action. It ensures that good and efficient teachers, adequate and accessible facilities and materials needed for effective teaching and learning and preparedness of graduates for meeting the challenges of life and for solving the societal problems are available

Akerele (2008) defined quality assurance as a set of elements that constitute the input and output process of education that provide services which satisfy the internal and external constituencies by meeting their implicit and explicit expectations. In a similar vein Oderinde (2004) made reference to quality assurance consisting two aspects, the internal and external. The internal aspect is concerned with the implementation of the school objectives while the external aspect deals with the implementation of national objectives, which are pre-requisites to the achievement of quality in any educational institution

Through quality assurance NUC guarantees employers the Nigerian public and the international community that university graduates have attained an acceptance level of competence in their areas of specialization and so are adequate for employment and further studies (Okebukola, 2006). Quality assurance in Nigerian Universities is a process of continuous improvement in the quality of teaching and learning activities to ensure Minimum Academic Standards (MAS) are attained, maintained and enhanced.

\section{Achievements of Undergraduate Programmes accreditation in Nigeria:-}

1. One of the remarkable achievements is the development and review of Benchmarks Minimum Academic Standards (BMAS) to guide Nigerian Universities in the development, implementation and evaluation of their curricula. Ensuring institutional compliance with the stipulated standards measured through specially designed accreditation instrument. No university in Nigeria operates or offers any undergraduate progamme without fulfilling and meeting the minimum requirements for the progamme as established by the NUC BMAS.

2. The NUC accreditation of undergraduate program has help in strengthening programmes for quality assurance and quality improvement. This process has aided the institutions in developing and sustaining effective educational programmes and assures the general public, and other organizations that the accredited institution has met high standards of quality and effectiveness.

3. Another success story of the commission is the continuous review of undergraduate programmes curriculum in line with global best practice. In 2005, the Commission introduced new academic curricula for all Nigerian Universities aimed at providing a better skilled and entrepreneurial graduates suitable for not only Nigerian but for the global market.

4. Through accreditation, the NUC is well informed on state of human and material resources available in the universities for better advice to the federal government on the needs of the universities in meeting the BMAS requirements for the offer of undergraduate programmes in the Nigerian universitie. 
5. The NUC in 2013/2014 established the carrying capacity for every programme to be offered in Nigerian Universities. Carrying capacity is the minimum number of students that the human and material resources available in the university can support for quality delivery of education (Oluremi and Kolade 2016).

6. The commission has succeeded in ensuring that only licensed private Universities are allowed to operate and close down all illegal universities for quality assurance in Nigeria.

\section{Challenges of Undergraduate Programmes Accreditation in Nigeria Universities:-}

It is true that NUC has recorded tremendous achievements in quality assurance of university education in Nigeria. The quality assurance function of the NUC has been mainly through the accreditation of the undergraduate programmes of Nigerian universities. These successes have not been without challenges. The following are considered potential challenges of the NUC in the accreditation of Undergraduate programmes in the Nigeria universities;

\section{Budgetary allocation:-}

Financing accreditation exercises of the undergraduate programmes in Nigeria is critical in achieving quality education in Nigeria. This is one of key components of the operations of the NUC as regulatory agency. Okojie (2008) observed adequate budgetary accreditation in the annual national budget would reduce the cost of sharing the accreditation's expenditure with the universities.

\section{Information dissemination:-}

Timely dissemination of accreditations panels' recommendations to universities for implementation has remained a challenge to the commission as observed Okojie's (2012) that the Commission still has difficulties in receiving accurate information promptly from universities. This problem has resulted in gaps in the information flow between the NUC and universities in the performance of its quality assurance functions. Without timely adequate information flow amongst the NUC, Universities and the general public, decision on quality assurance becomes difficult.

\section{Unhealthy relationship between Key stakeholders:-}

The relationship between Academic Staff Union of Universities (ASUU) and NUC has not been cordial as partners in progress and the major Stakeholders in the business of quality assurance of university education in Nigeria. Dada (2014), Oluremi and Kolade (2016) noted that the Academic Staff of universities have continued to perceive the NUC's quality assurance functions in university education as infringement of university autonomy and criticized its accreditation exercise, describing it as a steady subversion of the powers of University Senate. ASUU has persisted that, accreditation of degrees and academic programmes should be left to professional bodies empowered to regulate professional education and training or Universities Accreditation Committee specifically constituted by the Universities. Banji (2010) noted that NUC's quality assurance functions in university education are more of production of programme documentations and outcome information which have not substantially improved the Nigeria University System (NUS). This situation does not support management principles of cooperation for effective quality assurance of university education in Nigeria. Hence Ajayi (2007) advocated outright proscription of the NUC as it has become a Federal parastatal that could not be reformed.

\section{Monitoring mechanism of universities compliance to accreditation reports:-}

Dada (2016) observed that NUC was ineffective in monitoring Minimum Academic Standards in universities' academic operations, according to him it was an indication that NUC did not perform this role as expected. Monitoring is critical to assuring quality university education. According to Middlehurst (2001), monitoring starts from laying down of legal framework, observance of the legal framework, admissions, curriculum design and providing learning experiences which are worthwhile to the students and ends up with certification and awards. Banji, (2011) lamented that monitoring of the universities' observance of Monitoring Minimum Academic Standards has remained administrative procedure; emphasizing compliance and accountability which do contribute in effective transformation of students' learning experiences.

\section{Institutions policies and functions overlaps:-}

NUC was established with the mandate of coordinating and advising the Federal Government on matters relating to university education in Nigeria. Over time, the NUC has witnessed changes in terms of the organizational structure, policies and its objectives. Its scope of operations now covers accreditation of universities to ensure compliance with Minimum Academic Standards, approval and establishment of new universities and programmes (Dada, 2016). Similarly, the University Miscellaneous Act 2007, provides for institutional university autonomy which confers 
power on the university senate to establish programmes in the universities. These are viewed by the academic staff of universities as undue interference with universities operations. The expanded functions of the NUC appears not to be in harmony with the University Act, 2007 and this has implications for NUC's operations in terms its performance accreditation function in achieving quality university education in Nigeria.

There are also overlaps of functions of accreditation exercises between the NUC and other professional bodies; the Nigerian Medical and Dental Council (NMDC) accredits the professional Medical Programmes, the Council of Legal Education (CLE) assesses the professional Law Programmes; the Council for Registration of Engineering in Nigeria (COREN) accredits the professional Engineering Programmes Oladusun (2011). When this happens, there could be possibilities of variation in the result of the assessments by the two separate bodies is inevitable. This position may place the universities in dilemma in the pursuant of its mandate thereby making a mess of the entire accreditation exercise.

\section{Multiple tasks of the NUC:-}

NUC has metamorphosed from the original advisory role to the Federal Government on matters bordering on university education to multiple of functions. According to Oladusun (2011), the commission performs in addition to its accreditation function a number tasks to include strategic planning and management; Nigerian Universities System Annual Review Meetings (USARM); Facilitating linkages and collaboration with national and international development partners; Development of physical structures and facilities; Nigerian Universities Research and Development Fair (NURESDEF); Linkage with Experts and Academics in the Diaspora (LEAD); collects, analyses and publishes data for student projections and determination of Full-Time Equivalent (FTE); relates with the NUC, JAMB, WAEC, NECO, on matters bordering on the introduction of new academic programmes. More recently, Bassey and Archibong, (Dada, 2016) observed that the NUC is now engages in academic staff capacity building through the Virtual Institution for Higher Education Pedagogy (VIHEP), assessment of academic journals, ranking of universities and as well as curriculum review. These expanded functions have implications for effective performance of NUC accreditation exercises for ensuring that Minimum Academic Standards are maintained in achieving quality university education in Nigeria.

\section{Increasing number of universities and programmes in Nigeria:-}

Another challenge of the NUC is the ever increasing number of Federal, State and Private Universities in Nigeria. At the establishment of the commission, there were only four Federal universities in Nigeria. Oluremi and Kolade (2016) noted that regulating more than 129 universities in Nigeria effectively is increasingly becoming a burden too heavy for the National Universities Commission to bear alone. In addition, the numbers of universities in Nigeria have increased to about 129 Federal, State and Private Universities. Also giving rise in a geometrical increase in the number of programmes offered in the Nigeria universities. In 1990/1991, 837 programmes were involved in accreditation, by 2009/2000 accreditation exercise the number of programmes for accreditation that year rose to 1,119 and in 2005/2006 the number programmes for accreditation was put at 1670 programme (Okojie, 2008). As the number of universities increase, there is a corresponding increase in the number of programme offered and this undoubtedly place more demands on NUC accreditations exercises.

\section{Personnel:-}

Personnel is the driving force of any organization, other factors revolve round and remained dormant without personnel. Personnel with basic academic and professional qualifications and competencies is key in achieving organizational goal. 4Core professional personnel are still a challenge in the operations of NUC accreditation exercise. During accreditation, NUC draws Ad-Hoc staff from the universities.

\section{Conclusion:-}

NUC accreditation over the years has positively impacted on the universities' operations in Nigeria. Accreditation brought the unif44ormity in the programmes offered in over 129 registered universities in Nigeria. Through accreditation, facilities in the universities are upgraded in preparation for the exercise to meet with the requirements BMAS for accreditation. Much more can be achieved with concerted made to reposition NUC in the performance of it onerous accreditation, the quality assurance functions of university education for the universities to be producing graduates that would meet the labour market needs for a sustainable economic growth in Nigeria and who may found well prepared for postgraduate studies both locally and abroad. 


\section{Recommendations:-}

Based on the conclusion drawn, the following recommendations are made.

1. Adequate special budgetary provision should be appropriated from the federation account specifically for accreditation exercise, particularly now that NUC conducts accreditation two times in a year. This would reduce additional financial burdens of cost sharing of accreditation on the universities and NUC.

2. NUC should develop an effective strategy of monitoring universities to engender mutual understanding between the Academic Staff of universities and NUC as partners in progress for effective collaborations in quality assurance of university education in Nigeria.

3. NUC shoul set up Universities Information Network Centre (UINC) for effective circulation of information on the accreditation status of universities' academic programmes and the panels' reports for implementation by universities.

4. Federal Government to review policy for proper separation of powers and functions of the major players in quality assurance of university education. There should be a clear separation of the powers and functions of the university senate, NUC and other professional bodies that perform accreditation functions of undergraduate programmes in the universities in Nigeria.

5. Federal Government should scale down the multiple functions of the NUC by creating an agency that would handle other function performed by NUC which have no direct bearing with quality assurance for example, licensing private universities in Nigeria; Nigerian Universities Research and Development Fair (NURESDEF); Linkage with Experts and Academics in the Diaspora (LEAD) to mention but few.

6. Recruiting more core professional staff with qualifications across disciplines offered in the Nigeria universities, continuous training and motivating of available personnel that would engender zeal, passion, integrity, commitment, efficiency, effectiveness, resourcefulness among the staff of the commission.

\section{References:-}

1. Abubakar, S. (2015). Influence of accreditation exercise on academic standards in Colleges Of education in north-west geo-political zone, Nigeria. An unpublished M.Ed thesis, Ahmadu Bello University, Zaria.

2. Adegbesan, S.O. (2010). Establishing quality assurance in Nigerian educationsystem: Implication for educational managers. Educational Research and Reviews . 5(7): 380-384. Retrieved on $14^{\text {th }}$ June, 2013 from http://www.academicjournals.org/ERR2

3. Ajayi, I. A. and Haastrup, E.T. (2008). Management of university education in Nigeria: Problems and Possible Solutions. InAkpa, G.O.; Udoh, S.U. \& Fagbemiye, F.A. (Eds). Deregulating the provision and management of education in Nigeria. Jos M.P. Ginac Concept Ltd: 222 -235.

4. Akerele, W.O. (2008). Quality assurance in Nigerian's universities system. In Akpa, G.O.; Udoh, S.U. \& Fagbemiye, F.A. (Eds). Deregulating the provision and management of education in Nigeria. Jos M.P. Ginac Concept Ltd.: 84-121.

5. Banji, F.J. (2011). External quality assurance in higher education: The Need for a paradigm shift. Ondo: National Institute for Educational Planning and Administration. Retrieved on $6^{\text {th }}$ July, 2013 from www.merit.uni.edu.

6. Charnay, G. (2003). Accreditation and the Role of the Council on Post Secondary Accreditation (COPA) Washington D.C.

7. Dada, M.S. (2016). An assessment of national universities commission's effectiveness in quality assurance of university education in Nigeria. Bayero Journal of Education in Africa. 5 (1) p.206-215.

8. Ehindero S (2004). Accountability and quality assurance in Nigerian education. A paper presented at the international conference of the Institute of Education, Olabisi Onabanjo University, Ago - Iwoye. (Jan 12th 15 th)

9. Fafunwa, B. A. (1995). History of education in Nigeria. Ibadan: NPS Edu. Pub. Ltd.

10. Harvey, I. (2008). The Power of Accreditation: Views of Academics Journal of Higher Education Policy and Management. 26(2) $207-223$.

11. Imam, H. (2003). An organizational effectiveness study of joint admission and matriculation board's operation in university admission. Journal of educational management and planning. 1 (1): 40 - 47.

12. Materu, P. (2007).Higher education quality assurance in Sub -Saharan Africa: status, challenges, opportunities , and promising practices. Washington. World Bank. Paper No.124 Retrieved on 6\% $607 / 2013$ from www.merit.uni.edu. 
13. Middlehurst, R. (2001). Quality assurance implications of new forms of higher education. European network for quality assurance in Higher education. Helsinki. Retrieved on 21 October, 2011 from http://www.sagepub.com/journal.nav.

14. Moses, T R and David, K. A. (2008). Educational assessment and quality assurance, implication for principal instructional role. Retrieved on Monday, 6/7/2017 from www.educationalportal.com/articles/topschools.

15. National Universities Commission (2004). Report on the performance of the Federal University system in 2002 presented at the special meeting convened by the Honourable Minister of Education on The Standard deviations.

16. National Universities Commission (1988). 25 Years of Centralised University Education in Nigeria. (Ed.) A. U. Kadiri. Lagos: NUC.

17. National Universities Commission (2012). Manual of accreditation procedures for academic programmes in Nigerian universities (MAP). NUC.

18. Nwadiani, M. \& Iginewaka, V.O. (2005). Managing university education in Nigeria: the imperatives of deregulating government control. In Akpa, G. O.; Udoh, S. U.\& Fagbemiye, E. O. (Eds). Deregulating the provision and management of education in Nigeria. Jos: M. P. Gimic Concept Ltd.: 105- 188

19. Oderinde, B. (2004). Secondary education in Lagos State. A report of the state of Secondary education in Lagos State

20. Okebukola P.A. (2006). University Reforms. The Journal of Business Education 7(2): p.25- 31

21. Okebukola, P.A. (2004). The choice and Balance between Quality and Quantity in the Nigerian University System; Admission Quota for 2005/2006 National Universities Commission, Monday Memo 4(21) 1-4.

22. Okojie J. A. (2012). Battle for versity's soul. Retrieved on 6\% $/ 07 / 2013$ fromhttp://tribune.com.ng.

23. Okojie, J.A. (2008). Licensing, accreditation and quality assurance in Nigerian universities: achievements and challenges. Being Paper presented at asession of the 2008 CHEA Summer Workshop. Retrieved on $6^{\text {th }} / 07 / 2013$ from www.chea.org.

24. Okojie, J.A. (2010). The Nigerian university system: Challenges and prospect. Retrieved on $20^{\text {th }}$ march 2012 from http.www.nuc.edu.ng.org.

25. Oladosu, A.G.A.S. (2011). Accreditation in the Nigeria universities: The Role of the Academic Planner Training Workshop for Academic Planning Officers in Nigerian Universities, Organized by the Committee of Directors of Academic Planning of Nigerian Universities (CODAPNU) in collaboration with the National Universities Commission (NUC) on 12th -15th July, 2011 at the NUC Auditorium, Abuja.

26. Oluremi, O.F. and Kolade, O.B. (2016). Quality assurance in Nigerian university education: The role of the National Universities Commission (NUC) as a regulatory body. International Journal of Academic Research in Business and Social Sciences. 6 (12): p.160- 169. Retrieve on 14 August, 2016 from www.hrmars.com.

27. Oyebade, S.A. (2008). Privatization of universities in Nigeria. Implications for educational management. In Akpa, G.O.; Udoh, S.U. \& Fagbemiye, F.A. (Eds). Deregulating the provision and management of education in Nigeria. Jos: M.P. Ginac Concept Ltd.: p.321 -334.

28. Olorunfemi, A. I. Ashaolu, M. O. (2010).Quality assurance and engineering education development: appraisal of regulation models in Nigeria. Retrieved on 24 March, 2011 from http://en.wikipedia.org/wiki/Testdriven_development.

29. Onyeonuru, I. (2004). Industrial conflict in Nigeria university. The presence of the past and the thrust of the future. The national scholar 4 (5). A publication of Academic Staff Union of Universities.

30. Oyebade, S.A. (2012). Curriculum reforms and employability of graduates of educational institutions. A lead paper presented at 2012 biennial conference of school of education Federal College of education Abekuta, Ogun State.

31. Taiwo, C. O. (1994). Seventy years in Nigerian education system. Lagos: Thomas Nelson (Nigeria) Limited

32. Teacher's Registration Council of Nigeria (2010). Statistical digest of Teachers in Nigeria. 1 Abuja.

33. Uvah, I.I. (2005). The Quality Assurance Process in the Nigerian University System. In Munzali, J. (Ed). Perspectives and reflections on Nigerian higher education. Ibadan: Spectrum Books Ltd: 139-157.

34. Udom, O. U. (1996). Major Features of Accreditation in Nigeria. London: Routledge Information Ltd. Retrievev on $12^{\text {th }}$ august, 2016 from http://www.informaworld.com/smpp/title content=t713443244.

35. Rami, J. \& John, L. (2008). Multiplicity of methods in assessment as a form of quality assurance, quality control \& quality improvement. In implementing and using quality assurance: strategy and practice. A selection of papers from the 2nd European quality assurance forum. ENQA: European University Association. 